\title{
Formalistic as an Analysis Method in Signifying the Malay Cultural Symbol in Malaysian Modern Art of Paintings
}

\author{
Liza Marziana Mohammad Noh
}

Faculty of Art \& Design, Universiti Teknologi MARA (UiTM) Melaka, 78000 Alor Gajah, Melaka, Malaysia

Email: lizamarziana@ymail.com

Hamdzun Haron

Pusat Citra Universiti, Universiti Kebangsaan Malaysia, 43600 Bangi, Selangor, Malaysia Email: hh@ukm.edu.my

\begin{abstract}
Abdul Latif Samian
Institut Alam dan Tamadun Melayu, Universiti Kebangsaan Malaysia, 43600 Bangi, Selangor, Malaysia Email: abdlatif@ukm.edu.my

Ahmadrashidi Hasan

Faculty of Art \& Design, Universiti Teknologi MARA (UiTM) Melaka, 78000 Alor Gajah, Melaka, Malaysia Email: ahmadrashidihassan@yahoo.com
\end{abstract}

Doi:10.5901/mjss.2015.v6n4s2p30

\section{Abstract}

In order to appreciate an artwork, beauty is not the main issue to be studied, but instead, it is the elements that make up the beauty. Therefore, to investigate the elements, subjects, forms and meanings are the three aspects in the study of art that are used for such purposes. All these elements are interconnected and cannot be separated because of the unity of an artwork is formed from these elements, and further explained the ideas of artists. Thus, in defining the elements of artwork, it is important to study physical data that function by connecting the context of an artwork. The aim of this study is to examine the symbol of Malay cultural traditions in the context of visual art in Malaysia embodied by local artists as the expression of their cultural ideas. Accordingly, a qualitative descriptive study method has been adopted to identify the forms and meanings of the symbols of Malay cultural traditions in Malaysian visual arts. Two painting artworks from the 1980s and 1990s have been chosen in order to investigate their forms and meanings. After the independence, the symbols of Malay cultural traditions have been embodied by the artists in the search for artistic identity. The results of this study are expected to expose the public generally and art enthusiasts particularly, to appreciate the artworks. Hence, the Malay culture can be well preserved as today's young artists tend to choose the modern universal symbols rather than the symbols of community culture.

Keywords: Symbol, Malay Culture, Paintings;

\section{Introduction}

Art is a phenomenon of human beings activities. Human beings produce art in order to understand life or communicate ideas with other human beings. In the case of Lazzare \& Schlesier (2008: 4), it is stated that Art is a visual medium that is used to express our ideas about human experience and the world around us. Accordingly, in embodying the art of feelings, it is the dominant factor for human beings other than the interests of observation and experience. (Pooke \& Witham, 2010) Art is a symbol that is included in the symbolic levels of expressions, feelings or expressive symbols. According to TjepTjep Rohendi Rohidi (2000), human beings think, feel and behave in symbolic expressions. Each symbol has its own function and the symbol contains the beliefs that would normally be the essence of respective religions, the cognitive symbols that form knowledge, the symbols of moral judgments that form the values and rules, as well as the symbols of expressing feelings or expressive symbols. (Bachtiar, 1982) All of these are revealed based on the lives of human beings who live in the cultural context. As according to TjepTjep Rohendi Rohidin (2000: 74-75), human beings are biocultural creatures; the products of interaction between biological and cultural factors. This means that as 
cultural creatures, they cannot be separated from biological existence. The cultural life itself is maintained in biological populations and biophysical environments. It evolves and creates a culture with its biology. The way human beings dress up, process foods, build homes and communicate by languages, even the entire environment is the result of human interventions. Hence, that is why it is said that human beings cannot live without culture. (T. Jacob, 1982)

An artist cannot escape from connecting the essence of his art with the things that are related to culture. As biocultural creatures, artists convey their desires that appear from the souls of human beings that have been channeled through thoughts and practices over their lives through artworks. Thus, Winckelmann (1717-1768) in implementing the innovations of the art methodology by Vasari emphasized that the evaluation of an artwork is important to connect to its cultural history rather than the history of the artist. He explained that the cultural context is produced as part of the written history of art. (Ahmadrashidi Hasan, 2006). Artists such as painters, sculptors, designers or art printmaking experts always try to improve the sensibility and perception on cultural dynamics of the community because the issue is near and circling their lives. Artists as the creatures who are given the intelligence on the development of images or according to Earnts Cassirer as creatures who like to play with symbols, transform the sensibility through forms of symbols or pictures. Therefore, the forms of the symbols produced are not created from the sense of emptiness but they contain the values and aesthetics that reflect the ideas and aspirations of the creator on the socio-cultural of the community. Each artwork that is produced gives a certain value and specific meaning that is able to give benefits from the point of its appreciation or purpose. Meanwhile, value and meaning trigger symbolism or representation that displays the lifestyle, beliefs and rules of life, as well as give the sense to the person using it. This premise suggests that symbolism is an important aspect in the field of art other than its usability or function, as quoting the opinion of M. Habib Mustopo in his writings entitled "Ilmu "Budaya Dasar" in Kumpulan Esei Manusia dan Budaya (1983: 46)

One of the purposes of art in the society is to help preparing and forming the background of life. Art is the answer for humanitarian imperative requirements. Its main purpose is to improve the interpretation and complement life. In addition, art is also used as a helper for other purposes such as the glorification of religion, propaganda, symbolism and so on. (Muhammad Afandi Yahya, 1995: xvii)

Thus, it symbolizes the creativity and maturity minded of artists in bringing profound aesthetic taste through symbols that provide benefits to those who appreciate it and it does not give shallow taste of art. Artists as symbols creatures are different in terms of character from other human species because the symbols have become the medium of instruction in conveying their ideas about life. They create symbols, in which each symbol has its own role to convey the message. As according to TjepTjep Rohendi Rohidi (2000: 74),

The artworks created by human beings are not without purpose. In other words, every natural thing that is touched or worked out by human beings gives a new form that has a certain value, indicating the purposes and ideas of the creator. He/She is the symbol of the cultural scope.

This is proven from the ancient time where artistic symbols have been embodied for expressing ideas of arts with various purposes that have been produced by human beings. Day by day, it seems that the symbols change their processes due to different desires and purposes.

\section{The Symbol of Malay Culture as the Expression of Modern Art Painting}

The symbol of Malay culture is one of the symbols of art and culture that is embodied by local artists in the art of painting. Before painting was introduced, many forms of artworks which symbolized the Malay culture were found in the art of Malay handicrafts. (Liza Marziana Mohammad Noh, 2013) Art painting is part of the visual arts that has become the communication medium for artists in conveying ideas through art symbols. The art of painting has the form of a twodimensional surface and it becomes a space for artists to explore the symbols of their arts through various techniques and mediums of colours. Referring to the evidence, the symbols of art which were embodied from the paintings produced by human beings since ancient times up to the Renaissance in Italy, are in the forms of representation and nonrepresentation.

Generally, human beings communicate through media form, which is called a sign, but is a special sign. The sign is more universal and is not bounded by culture. (TjepTjep Rohendi Rohidi, 2000) The difference between a sign and a symbol is that a sign is the one marks and is marked for example, when there is smoke, definitely there should be fire, and smoke is the mark that signifies that the fire is there. Meanwhile, a symbol is a special sign that is arbiterer, which means that it is different from the one that is marked. A symbol can only be understood as a specific cultural context that 
is interpreted by the culture itself (Keraf, 1980)

There are many definitions of culture. This statement actually refers to the writings of Kroeber and Kluckhohn (1952) entitled Culture: A Critical Review of Culture Concept and Definition, which listed more than 160 definitions of culture. The next definition is modified in different views of specific fields such as anthropology, sociology and ethnology. (Anwar Din, 2008) Nevertheless, overall, it can be concluded that culture can be defined as the beliefs, customs and arts of a society, group, place or time. As described by Burnett Tylor (1871), culture is something complex that encompasses knowledge, belief, art, law, morals, customs and other capabilities that are created by human beings for their societies. The culture norm is something that is respected by every member of society, from the family or from the outside elements. (Rasid Ismail, 2014)

Meanwhile, Malay also gives a broad meaning. By taking social and cultural definitions, the term Malay refers to people living in Peninsular Malaysia and in the wide territories of the Archipelago, which include Peninsular Malaysia and thousands of islands that formed the Republic of Indonesia and the Philippines today. (Milner, 2011, Syed Husin Ali, 2008) Although the Malay is divided into several groups and has a variety of languages, dialects and cultures, but yet, they are of the same stock, therefore it is known as Malay or Malayo-Indonesian. (Syed Husin Ali, 2008) The concept of Malay in the context of Malaysia, according to Anwar Mohammed, is that the existence is not from a single lineage. Partly, it is made up of natives in Peninsular Malaysia, partly descended from Indonesia while other communities such as Arabs, Indian, Siamese, Chinese and European who become Muslim Malays. It means that the Malays were formed from a combination of various ethnic groups. The basis of such combination is the religion of Islam and the Malay language. Therefore, the reality of the Malay existence today is in tandem with the definition of Malay given in the legislation that defined the Malays by the Malaysian Federal Constitution (Article 160 (2), in which the Malay means a person who adheres to Islam, commonly speak Malay and follow Malay customs. (Anwar Din, 2008) Accordingly, with the diversity of ethnics, it produces a wide variety of cultures in the Malay community. The culture in the community encompasses all activities and practices performed on a daily basis inclusive of arts to meet the time or source of income. (Rasid Ismail, 2014)

As such, the embodiment of Malay cultural symbols on the art of painting is specific to the Malay culture itself. Based on every artwork, it has always reflected the bias into one cultural category by the artist who created the work. There is no denial that art has its roots in the social life, and there is no artwork whether painting, music or literature can be understood which stays apart from the personal genius who invented it, the race of the people who is active will penetrate into themselves. Based on that, according to Deutch (1975) in Darsono Sony Kartika (2007), an artist as the source of information forms a perception of cultural bias that leads to the formation of character and colour of the subject or the object as he/she forms the basis of its aesthetic expectations and requirements. Hence, the symbol of Malay culture that is embodied is a creation of bias perception of an artist who has strong race relations on himself/herself. The tendency and understanding towards his/her culture yield the cultural symbols that are formed based on the aesthetic order of an artist through the reflection of Malay culture such as its customs, taboos, religions or beliefs, as well as manners and ethics.

The symbols of Malay culture on the art of paintings have begun to receive the attention of local artists since the country gained independence with some batik painters, from the Wednesday Art Group and the Peninsular Artists Force (APS) that highlighted the subject of arts and the community as part of the Malay culture. (Muliyadi Mahamood, 2001). Their works reflect the bond of arts among the community that portrays their attempts in refining the culture of the community that forms some parts of their practical lives. Most of the symbols embodied in the objective forms that are known as representations. The cultural tendencies of paintings are the reminiscent of Dolores D Wharton's statement who was able to experience the struggle to preserve the heritage and identity of national arts when she was in Malaysia around 1958-1964. Her statement reads:

While one can still not say that there is a Malayan "school of painting, the search for some form of identity began during this period."(D'zulhaimi, 2006)

The struggle was also noticed by Howard Taubmann of the New York Times through the First Triennal of Contemporary World Art exhibition in New Delhi in 1968. He believed that the traditional themes in the modern context through the artworks of Malaysia have shown the brave efforts undertaken by the artists. (D'Zulhaimi, 2006)

The struggle was also noticed by Howard Taubmann of the New York Times through the First Triennal of Contemporary World Art exhibition in New Delhi in 1968. He believed that the traditional themes in the modern context through the artworks of Malaysia have shown the brave efforts undertaken by the artists. (D'Zulhaimi, 2006)

In the 1970s until the 1990s, shortly after the organization of the National Cultural Congress, the event saw a 
symbol of Malay culture embodied actively through the participation of local artists. The active embodiment arose due to the awareness on the importance of identity in the works. The tragedy that occurred in 1969 has opened up the eyes of all parties on the fragile identity of Malaysians. (D'Zulhaimi, 2006) Likewise, the resolutions were achieved through the Congress in finding a formula for the establishment of a national culture to unite the people, and they have set three important concepts as the basis of national culture:

1. The National Culture should be based on the original culture of the people of this region.

2. The elements of other cultures that are appropriate and reasonable may be accepted to become the elements of a national culture.

3. Islam becomes an important element in the formation of a national culture.

Subsequently, it has given an impact to the field of art, specifically to the local artists in search of their identity in art. According to Zakaria Ali, when non-Malay artists did not mention about the National Cultural Congress, the Malay artists saw it as an opening of the direction in creating a new era in art. In the 1970s and 1990s, the era of growth to the symbol of Malay culture was actively embodied by most Malay artists. (Siti Zainon Ismail, 2012)

\section{Formalistic Approach in Signifying the Symbols of Malay Culture in Modern Art Paintings in 1970-2003}

Reading the beauty of visual arts is not the main point to be studied; instead, the elements that make the beauty of the visual arts. (D'Alleva, 2012) It does not matter whether it is an art of painting, printing or sculpture, or design of elements that becomes the physical data of artwork and often prevails in the spotlights. These elements (the properties of works of art) play the role in shaping or building a form of art, whether in the form of representation or non-representation. (Pooke \& Whitam, 2010) As a symbol of Malay culture, it is composed of the elements that form the basis for the formation of an image and it is known as formalistic. Cultural symbols are dealt with intellectually through the elements of lines, shapes and colours, and the next texture is composed well by the local artists. With that, the significant formation of Malay culture can be embodied appropriately with the subjects and ideas presented.

In the 1970s and 1990s, the symbols of Malay culture had been widely produced. These developments occurred after the National Cultural Congress was held, in which the values that are beneficial to the society had been widely produced. For Malay artists in particular, the emphasis was on the ethnic consciousness that made them tried to uncover all of their origins and cultural heritage. The situation did not deny the existence of art intellectual's involvement comprising Malay/Muslim revivalist artists who intellectually created new cultural symbols in upholding the concept of art for the society. With that, it witnessed the embodiment of Malay cultural symbols which were actively produced with various characters of Malay cultural symbols as a result of the artist's perception that was biased towards culture. This is in line with Tolstoy's art concept who said that:

In order for art to be placed among those other areas of knowledge and to be considered as amelioration according to Tolstoy's concept of art, it must have a form which is based upon intellectual ideas and free of deficiency. Tolstoy was seeking a criterion of value and assumed that the pursuit of art can be justified only if some ulterior benefit can be seen to derive from it. (Mohamed Ali Abdul Rahman, 2000: 9)

According to Clive Bell in Pooke \& Witham (2010), a work of art is a product of art that is capable to spark emotional and aesthetic reactions of the observers. They respond to the work of art based on the subject (idea), form (materialized form) and meaning (content) that are delivered. However, among all these three, form is often chosen to be the topic of discussion. Dewey (1980) explained that the early history of philosophy believes that form is seen as containing the intrinsic value within it and this is because the essence of any formation is based on the metaphysical structure of the nature. It can be associated with the classical theory by the founder of the doctrine of mimetic art, Plato who defined work of art as having the elements that are derived from the ideal forms of the outside world of the artwork itself. (Rahmah \& Norazlin, 2002) The concept of mimesis by Aristotle is an incarnation of the actual objects that are organic and structured. Aristotle gave more attention on the art of representative, which he thought is capable to evoke emotion. It is associated with the cases of the tragedy of his drama, which left the emotion of pity and fear to those who appreciate it. Similarly to Eisener, Elliot \& Ecker (1966) who also considered that the work of art as a real imitation that includes universal values. Nevertheless, the representative is not really meant to imitate the whole thing but it is a representation of thought that represents the reality embodied from the human mental development.

Therefore, the one that appeals to the observers is the form that contains the elements of formalistic that has been organized into the specific compositions. Bell stated that when observers react, it is the key to visual experience.

We respond to a work of art- either figurative (One that resembles our visual experience of the world) or abstract (one 
that does not)-because we consciously or unconsciously respond to its compositions or formal arrangement. (Pooke \& Witham, 2010)

Observations by observers are different. The way they perceive art is based on their personality, which is established through education and purposes, as well as the interests of the observers. In order to understand the work of art, analysis and evaluation are important criteria in understanding the whole process. In the field of art criticism, most art critics in the 20th century believed that formalistic approach is more relevant to discuss about art. Clive Bell and Roger Fry, Wofflin emphasized that formal characteristics make an artwork more meaningful and important compared with the subjects displayed. According to them, the characteristics apply to all the works of visual art. Bell (1914) thought that the elements of lines, shapes and colours in a certain way are capable of evoking the importance of the form.

To appreciate a work of art we need bring with us nothing from life, no knowledge of its ideas and affairs, no familiarity with its emotions...nothing but a sense of form and colour. (Pooke \& Witham, 2010)

Moreover, for the importance of the form, Bell argued it as to provide the interaction to the specific meaning that is formed through the qualities of art, namely formalistic elements. Bell's argument was also affirmed by Greenberg that the value of an art is based on the formal qualities. Consequently, there are three formalistic approaches developed by Greenberg to assist in understanding the form of an art. (D'Alleva, 2012)

1. Formalistic approach emphasizes the visual quality of the artwork, whether the layout of the elements and brush strokes.

2. Makes actual views or image experiences as something important, and the history of art is about how to view.

3. Formalists also stressed on stylistic and analyze it analytically and typically, tend to observe social, cultural aspects and political context widely through the art produced.

Form is part of art components. Form refers to the overall layout artwork. Form refers to the external image or formalistic that consists of lines, shapes, colors and tones which are then processed using the principles of art that build the unity in the artwork. Furthermore, formal elements can also be helpful in illustrating meaning and importance. The elements of art or formalistic become the basis for producing a design in an artwork. The art elements serve to embody the subject matter that is physical in nature.

As a method in exploring pictures, the aspect of formalism prefers to emphasize on viewing the form rather than assessing the meaning and narrative or even viewing to what is presented (subject matter). (Pooke \& Newall, 2008) This method suggests to those who appreciate art to investigate the elements of formalistic, which act as a developer to the form and function in providing the meaning as the formalistic elements that capable of conveying feelings, ideas or information. (Pooke \& Witham, 2010) In the art of painting, visual elements including lines, shapes, colours and tones are embodied from the effects of the technique and media used by the artists. The combined results lead to the formation of a composition that includes rhythm, results of the equilibrium from the organizational of elements of lines, shapes and colours. This is mentioned by Ragan as the language of art that forms the visual of symbols, which are capable of conveying the communication of idea. Panofsky, or even T Barret including semiotician who submitted the study to review the images, could be diverted from discussing about formal elements as a function to give the meaning. Therefore, in detecting symbols of the Malay culture, formalistic is the most appropriate approach to help in understanding them.

In summary, formalistic is an approach that emphasizes the way something is selected, rather than to view what is presented. In order to make the work of visual art a success, the form and subject must be compatible with the contents. In terms of meaning, Finch (1974) explained that meaning is the need of the artistic and contents to the artwork. Artistic needs are the reasons why the work of art is produced, while the contents are the results of the manifestation of the needs of the created object. Therefore, the contents consist of pure ideas of an artist and the evidence of ideas in a form of artwork. The contents do not just react to the artist himself/herself, but also to a group of artists, community or likely to the culture.

\section{Formalistic Analysis on the Symbols of Malay Culture in the Art of Paintings in the 1980s and 1990s}

In this analysis part, formalistic method was used to study the form and meaning of Malay cultural symbols. Therefore, observations were used to detect other forms of the symbols. Elements such as shapes, colours, lines, texture, tones with balanced art principles, harmony, unity, and repetition were analyzed. The advantage of this formalistic method is as explained by Carrol (1999: 129); it is able to discover the hidden meaning in the artwork.

Important issues will be answered through a systematic process. As you go through the step of description and 
analysis, you will collect facts and clues. When you get to interpretation, you will make guesses about what message you think the artwork is communicating. Finally during judgment, you will make your own decisions about the artistic.

A total of four paintings by local artists in the 80 s and 90 s have been selected to be analyzed. Among them are,

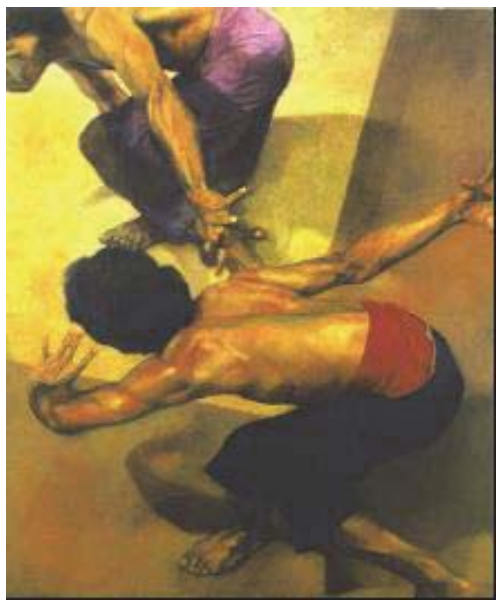

Examination of Artwork 1

Title: The Battle (Pertarungan), Year: 1983, Media: Oil Paint Measurement: 120 x 120 cm; By Amron Omar

For the first research artwork, the author chose Amron Omar's work entitled "Self Portrait" or "Potret Diri". Amron Omar is the second generation artist who studied at Universiti Teknologi MARA in the late seventy's. Amron Omar makes mimetic theory as his theory of art and figurative subject as the image. Amron's expertise in the use of oil paint and high accuracy of perception, as well as the ability or natural talent in drawing figures, has made him very successful. (Ahmadrashidi, 2003). It is recognized by Redza Piyadasa (2002: 116), his realistic, represented rendering of his chosen themes have been enhanced by his accomplished handling of human anatomy. Amron used the tones from light to dark, including shadow to embody his idea of realism. The two forms of his figures posed in the state of a battle were clearly illustrated by Amron Omar with great accuracy without the modification of forms. In terms of clothing of the figures, it was displayed by wearing a single style of clothing for a fight, which described the practices of a society. Both did not wear shirts and only wear pants. The subjects were composed in the middle position horizontally, which are refined in the aerial perspective. Amron seemed to emphasize only the fight action of two figurative who faced each other and ready for a battle. The muscular characteristics on the parts of the body of his figurative were clearly illustrated by Amron to symbolize strength and agility. The figure at the bottom was displayed in full, whereas for the figure at the top, the composition at the part of the head and body was not fully reflected as though it was accidentally cropped through the painting frame. Such situation is a reminiscence of the approach undertaken by Degas through his art of paintings by suggesting ideas outside the parameter space. (Redza Piyadasa, 2002). This recommendation aims to encourage those who appreciate the art to feel the artwork outside the viewing normality. The most interesting part can be enjoyed through the work of Amron is the way he records the shadow aspects naturally. It seems clear on the reaction from this work of Amron, which showcases the battle action forms that represent the characteristics of a particular culture.

Therefore, in order to connect it with the meaning, the battle painted by Amron Omar is from the perspective of cultural context. Its presence in the form of representation is a display from the reality of the world that happens around him. The artwork of Amron Omar is a representation of environmental and cultural issues that displays the beauty of martial art that was created among his community. In this case, Amron connects the subject of Malay traditional martial arts (Silat) that was used by ancient heroes or warriors. Silat is a popular martial art to the present day among the Malay community as a form of exercise or to be performed at wedding ceremonies. 


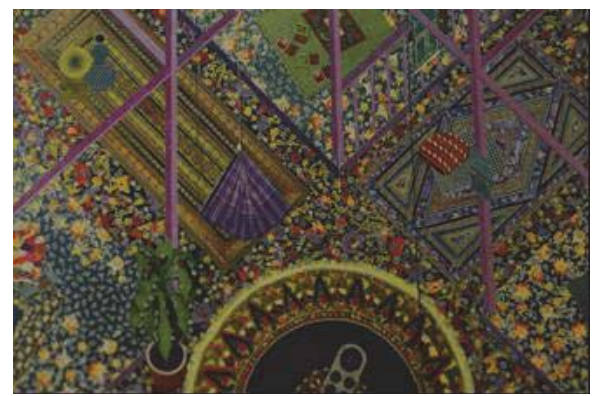

Examination of Artwork 2

Title: House of Flowers, House of Harmony, Year: 1999, Media: Mixed Measurement: 83 x $276 \mathrm{~cm}$; By Mastura Abdul Rahman

For the examination of the second artwork, the author chose the work of Flower House, House of Harmony 1999 by Mastura Abdul Rahman. From the point of formalistic, the authors found that the method of making this work is complex because it is made of three separate wood panels subsequently merged into one piece of surface and measuring $83 \mathrm{x}$ $276 \mathrm{~cm}$. Mastura chose the subject of interior decorations of the Malay traditional house that was inspired by the traditional house of the Malay noble group. In order to further strengthen the beauty of interior decorations, images such as baby cribs, rugs, vases, prayer mat, Sura of Yasin, congkak, labu sayong, pillows, calendars, masts of the house including floral motifs (floral from motifs of Malay textile/Archipelago) were used to display the interior decorations of the Malay residential. Mastura matched the batik ornamentation with the concept of a Malay residential space that was displayed from the top view. In addition, Mastura also connects her works with the traditional ornamentation in Islamic art, which is smooth and detailed as reflected in the architecture of the mosque or the miniature painting. According to Muliyadi Mahamood (2002: 20), in this context,

Mastura matched the global aspects of Islamic art with the local style, supported by formalistic policies in the form of styling, repetition and no emphasis on individuality.

In translating her aesthetic ideology, Mastura used the approach of the Western art style in expanding the interpretation of depiction aspects. Mastura managed to uncover a form of critical understanding about the concept of a new depth to distinguish the concept of the conventional space of three-dimensional in nature. She inspired the interior architecture of Malay traditional houses in isometric perspective, which is prevalent in architecture by using structured lines painted diagonally. The spaces on the architecture were filled with motifs of traditional Malay and Islamic ornamentations that were patterned with bright colours, which aimed not to allow for the creation of three-dimensional illusion of space. As a result, the visual effects of this work show the concept of space that is flat and shallow. Redza Piyadasa (2002: 104) explains

The spatial effect of the work has been heightened by the use of structural lines and foreshortened shapes that are derived from western perspective influences. Yet the visual effect of the work is a flattened, two dimensionality, induced by her concerns with the ornamentation of her surfaces.

In terms of the colours refined, it seems that Mastura used contrast bright colors. There was an occurrence of the colour analysis applied carefully by Mastura in matching the colours on the subjects she chose. Her work highlighted the complimentary colour, such as hot and cold colours or neutral colours in a state of low-intensity of colors. Thus, the effects of harmony and joy radiated through the work. The emphasis on colours in the works of Mastura has enriched the decorative style in the large range of colours. These factors stimulate the eyes of the observers by continuously appreciate every colour patterns created by Mastura. As according to Lazarri \& Schlesier (2008: 34),

Warm and cool colors can affect an audience both physically and emotionally. Certain colors in the surroundings can actually influence your alertness, sense of well-being, and sense of inner space. Colors can be symbolic and, thus associated with ideas or events.

In terms of meaning, Mastura works can be connected with the concept of femininity. The life related to marriage has inspired Mastura to explore the nature of femininity that she went through. She displayed the feeling of affection and 
love for her husband, children and the married life, which are symbolically embodied and implicit. The feeling has successfully been translated by Mastura through images and compositions that were arranged with the utmost order and carefully to create happy, charming and harmony atmosphere for the subject. This means attitudes that emphasize neatness, elegance, beauty and harmony symbolize the personal touch of Mastura on her taste. Thus, the selection of interior decoration images with the nature of Malay and complimented with floral motif ornamentation is compatible with her themes that reveal the passion and soul of Mastura towards the environment.

\section{Conclusion}

In order to understand an artwork, formalism is an appropriate approach to help in understanding the artwork. Theory of modern art by formalists and Greenberg has made feelings, observations and experiences on images as the motivation and important, as well as no reason can be given because the history of art is about viewing. Accordingly, both artworks that have been analyzed clearly connect the ideas from the perspective of the Malay culture. Both artists used the style of representation as a symbol to convey the meaning of the Malay culture, particularly from the art of the Malay traditions such as martial arts and traditional Malay house interior decorations. Obviously, both of these artists successfully adapted the context of Malay civilization through formalistic elements that make up the appropriate and more concrete symbols of arts. In conclusion, the Malay cultural symbols on paintings are the reflections of the heritage of the Malay community. With the efforts undertaken by some artists that have been analyzed, it is obvious that they have managed to highlight the form and meaning of cultural traditions to the modern recitation that were only manifested in the traditional arts previously. Hence, new generations should emulate these efforts by doing the experimentation of form and meaning of a culture so that it is not outdated. By approaching and appreciating cultural heritage, a self-identity will be embodied. In this case, Awang Had Salleh (1992) expressed that if we hope for the existence of appreciation on some elements of Malay arts into works of modern arts, thereby such an approach should be taken to understand closely on the Malays. If the artists restrict themselves by just only viewing without mindful of their souls, then the artists only paint the surface aspects of appearance alone.

\section{References}

Abdul Rasid Ismail. (2014). Alam Sebagai Motif Kraftangan Fabrik Melayu Tradisi. Kuala Lumpur: UiTM Publisher. Ahmadrashidi Hasan. (2006). Seni Lukis dan Idea. Shah Alam: Universiti Teknologi MARA.

Anwar Din. (2008). Asas kebudayaan dan Kesenian Melayu. Bangi: Universiti Kebangsaan Malaysia.

Bakhtiar, H. W. (1982) Birokrasi dan Kebudayaan. Cultural Analysis. Jakarta: The Department of Education and Culture.

National Art Gallery. (2000). Rupa Malaysia. Review of Malaysia Modern Art. Kuala Lumpur: National Art Gallery.

National Art Gallery. (2002). Masterpieces from the National Art Gallery of Malaysia. Kuala Lumpur: National Art Gallery.

Carrol, N. (1999). Philosophy of Art: A Contemporary Introduction.London: Routledge

D'Avella, A. (2012). Methods \& Theories of Art History. Second Edition. United Kingdom.

Laurence King. Kartika, D. S. (2007). Kritik Seni. Bandung: Rekayasa Sains.

Jacob, T. (1982). Manusia Indonesia sebagai Episoda dalam Koevolusi Biokultural. Analisis Kebudayaan. Jakarta Department of Education and Culture.

Kanansky, D. (1988).Contemporary Painting of Malaysia.Kuala Lumpur: National Art Gallery.

Keraf, G. Dr. (1980). Komposisi. Jakarta: Nusa Indah.

Lazzare, M \& Schlesier, D. (2008). Exploring Art: A Global, Thematic Approach. 3rd. Edition. USA: Thomas Learning, Inc.

Milner, A. (2011). The Malays. Malaysia: Wiley Blackwell.

Mohammed Ali Abdul Rahman. (2000). Modern Malaysian Art: Manifestation of Malay Form and Content. Shah Alam: Universiti Teknologi Mara

Muliyadi Mahamood. (2001). Era Pencarian Identiti Dalam Seni Moden Malaysia. Dalam Seni Lukis Moden Malaysia. Kuala Lumpur: Utusan Publication Distibutors Sdn. Bhd.

Muhammad Afandi Yahya. (1995). Simbolisme Dalam Seni bina Rumah Melayu. Kuala Lumpur: Dewan Bahasa dan Pustaka.

Pooke, G \& Witham. (2010). Understand Art History. United Kingdom: Hodder Headline.

Pooke \& Newall. (2008). Art History. The Basic. London: Routledge.

Siti Zainon Ismail. (2012). Imagining Identities. Narratives in Malaysian Art. Menulis dan Melukis: Writing and

Drawing in Malay Traditional Art and Their Impact in Modern and Contemporary Art-A Study of Cultural Values. Kuala Lumpur: Roger Art.

Rahmah Bujang \& Nor Azlin Hamidon. (2002). Kesenian Melayu. Kuala Lumpur: Universiti Malaya.

Redza Piyadasa. (1981). Pengolahan Lanskap Tempatan dalam Seni Moden Malaysia, 1930-1981. Kuala Lumpur: National Museum.

Redza Piyadasa. (2001). Rupa Malaysia. Meninjau Seni Lukos Moden Malaysia. Kuala Lumpur: National Art Gallery.

Rohidi, R. T. (2000). Kesenian dalam Pendekatan Kebudayaan. Bandung: Accent Graphic Communication. 
Syed Husin Ali. (2008). The Malays. Their Problems and Future. Kuala Lumpur: The Other Press.

Taylor, E.B. (1994). Primitive Culture. London: Routlege/Thoemmes.

D'zulhaimi Md Zain. (2006). The Conference of The Cultural Arts and Heritage. Pendidikan Seni Budaya dan Warisan di Abad 21: Teori dan Praktis. Kuala Lumpur: Aswara. 